\title{
LAS IMPLICACIONES CONSTITUCIONALES DE LA CRISIS: UNA RESEÑA DE LA LITERATURA RECIENTE
}

\author{
Giuseppe Martinico*
}

doi: 10.18543/ed-64(1)-2016pp23-38

\begin{tabular}{l} 
SUMARIO: 1. ESTRUCTURA Y OBJETIVOS DEL ARTÍCULO. 2. UNA PANORÁ- \\
MICA DEL DERECHO ANTI-CRISIS. 3. EL CONCEPTO DE MUTACIÓN CONSTI- \\
TUCIONAL. 4. ASIMETRÍA E INTERGUBERNAMENTALISMO. \\
\hline
\end{tabular}

\section{ESTRUCTURA Y OBJETIVOS DEL ARTÍCULO}

Este artículo explora los principales puntos de vista académicos relativos a las mutaciones de la estructura constitucional de la Unión producidas tras la crisis. Con este propósito el término «mutación constitucional» no debe entenderse como una completa ruptura con el pasado. Por ello este artículo tratarà de enfatizar esta idea a través del análisis de las continuidades y interrupciones en la visión tradicional del proceso de constitucionalización de la UE.

Tras aclarar el concepto de «mutación constitucional», en este artículo identificamos dos potenciales factores de mutación constitucional que han sido o bien

* Profesor titular de Derecho Público Comparado, Scuola Sant'Anna, Pisa, Research Fellow Centre for Studies on Federalism, Turin. Honorary Professor, European Law Research Centre, Henan University, Kaifeng. Expert Centre for Judicial Cooperation EUI. Todas las páginas de internet han sido consultadas por última vez con fecha 18 de abril de 2016. Este trabajo se enmarca en el Proyecto de investigación de la Subdirección General de Proyectos de Investigación del Ministerio de Economía y Competitividad: «Las mutaciones de la Constitución económica de la Unión Europea» (DER2013-48327-C3-2-R) y en el Proyecto «Gobernanza económica europea y transformación constitucional» (MINECO, DER2014-57116P) . Quiero dar las gracias a Justo Corti Varela y Carmen Román Vaca. 
creados, o bien fomentados por la crisis: la asimetría y el retorno al intergubernamentalismo. Pondremos particular atención en el Tratado de Estabilidad, Coordinación y Gobernanza en la Unión Económica y Monetaria (TECG), al ser ésta la medida que más interés ha suscitado entre los constitucionalistas, debido principalmente a su artículo 3 y su impacto sobre el sistema de fuentes nacionales ${ }^{1}$.

El debate sobre las implicaciones constitucionales de la llamada crisis de la UE es muy rico y multidisciplinar, así que es imposible tratar de representarlo de una manera completa ${ }^{2}$. Además, existen diferentes interpretaciones de lo que es realmente la crisis de la UE y diferentes lecturas del origen esta crisis $^{3}$. Es posible identificar dos visiones sobre la crisis económica: la que acusa a la UE de ser la principal responsable de la crisis y la que asigna la responsabilidad principalmente a los Estados miembros ${ }^{4}$. Esta segunda visión hace hincapié en el papel de los Estados, cuyas políticas fiscales irresponsables habrían amplificado la crisis ${ }^{5}$. La primera visión, en cambio, acusa

1 Art. 3.2 TECG: "2. Las normas establecidas en el apartado 1 se incorporarán al Derecho nacional de las Partes Contratantes a más tardar un año después de la fecha de entrada en vigor del presente Tratado mediante disposiciones que tengan fuerza vinculante y sean de carácter permanente, preferentemente de rango constitucional, o cuyo respeto y cumplimiento estén de otro modo plenamente garantizados a lo largo de los procedimientos presupuestarios nacionales».

2 J. Habermas, The Crisis of the European Union: a Response, Cambridge, Polity, 2012; P. AthanAssiou, Of Past Measures and Future Plans for Europe's Exit from the Sovereign Debt Crisis: What is Legally Possible (and What is Not), European Law Review, 2011, p. 558-575; V. Borger, How the Debt Crisis exposes the Development of Solidarity in the Euro Area, European Constitutional Law Review, 2013, p. 7-36; A. BuZELAY, À propos de la crise américaine et de son impact sur la zone euro, Revue du Marché Commun et de l'Union Européenne, 2009, p. 17-21; M. Poiares Maduro, M. Kumm, B. DE WitTe, B., The Euro Crisis and the Democratic Governance of the Euro: Legal and Political Issues of a Fiscal Crisis, Policy Report of the EUI Global Governance Programme, 2012, <globalgovernanceprogramme.eui.eu/wp-content/uploads/2012/06/Policy-Report10May20121.pdf>; A. HINAREJos, The Euro Area Crisis and Constitutional Limits to Fiscal Integration, Cambridge Yearbook of European Legal Studies, 2012, p. 243-268; J. V. Lous, The Unexpected Revision of the Lisbon Treaty and the Establishment of a European Stability Mechanism, en D. Ashiagbor, N. Countouris y I. Lianos, I. (eds.), The European Union after the Treaty of Lisbon, Cambridge, Cambridge University Press, 2012, p. 284-320.

3 A. MEnÉnDEZ, The Existential Crisis of the European Union, German Law Journal, 2013, p. 453-526, p. 453. Vease tambien: R. Dehousse, Le tre crisi del continente malato, Il Mulino, 2012, p. 485-496; K. TuORI, The European Financial Crisis - Constitutional Aspects and Implications, EUI Working Papers LAW 2012/28, 2012, <cadmus.eui.eu/ handle/1814/24301>.

${ }^{4}$ Entre otros: A. MENÉndeZ, The Existential Crisis cit., p. 454.

5 M. Poiares Maduro, A New Governance for the European Union and the Euro: Democracy and Justice, RSCAS Working Paper 2012, <https://papers.ssrn.com/sol3/papers.cfm?abstract_id $=2180248>$. 
a la UE de no haber sido capaz de corregir algunos defectos presentes en la arquitectura económica europea ya desde 1992 (año de la firma del Tratado de Maastricht).

\section{UNA PANORÁMICA DEL DERECHO ANTI-CRISIS.}

Como es bien sabido, la arquitectura económica de la UE se basa en cuatro pilares principales: 1) la coordinación de las políticas económicas entre los Estados miembros; 2) la coordinación de las políticas fiscales, en particular a través de los límites a la deuda pública y el déficit; 3) una política monetaria centralizada con un Banco Central Europeo (BCE); y 4) la creación de una moneda única (euro) ${ }^{6}$.

Entre las principales anomalías del sistema han sido señaladas las siguientes: la persistente asimetría entre la unión monetaria (centralizada) y la unión económica (consistente en una mera coordinación de las políticas económicas nacionales); el mandato incompleto del Banco Central Europeo (si se compara con el mandato pleno de un Banco Central federal); el limitado presupuesto de la UE; y la incertidumbre que rodea a las políticas presupuestarias de la Unión; junto con las debilidades del Pacto de Estabilidad y Crecimiento ${ }^{7}$. Todos estos defectos se hicieron visibles con la explosión de la crisis griega, que obligó a la UE a encontrar una solución para mantener a Grecia en la eurozona ${ }^{8}$. La crisis griega produjo una escalada de medidas que comienza con una Decisión del Consejo de 10 de mayo de 2010 con el «objeto de reforzar y profundizar la supervisión presupuestaria y de formular una advertencia a Grecia a fin de que adopte las medidas para la reducción del déficit, considerada necesaria para poner remedio a la situación de déficit excesivo» ${ }^{9}$. A esta decisión le siguió una serie de intervenciones más estructuradas pero sin una línea política clara que las fundamente ${ }^{10}$. El Tratado de

${ }^{6}$ C. DegRyse, The new European economic governance, Working Paper European Trade Union Institute 2012/14, 2012, <www.etui.org/Publications2/Working-Papers/ The-new-European-economic-governance $>$.

7 P. Krugman, End This Depression Now!, London-New York, Norton and Company, 2012, especialmente el cap. 10.

8 J. V. LouIs, The review of the stability and growth pact, Common Market Law Review, 2006, p. 85-106.

${ }^{9}$ El texto de la decisión n. ${ }^{\circ}$ 2010/320/UE se encuentra aquí: <eur-lex.europa.eu/LexUriServ/LexUriServ.do?uri=OJ:L:2010:145:0006:0011:ES:PDF>.

${ }_{10}$ M. Ruffert, The European Debt Crisis and European Union Law, Common Market Law Review, 2011, p. 1777-1806; V. PaLIOURAS, Why Europe Should Say No to the Proposed Framework of Economic Governance: A Legal and Policy Analysis in Light of the Establishment of the European Stability Mechanism and the Euro Plus Pact, 2011, <papers.ssrn.com/sol3/papers.cfm?abstract_id=1908435>. 
estabilidad, coordinación y gobernanza en la Unión económica y monetaria (TECG), firmado por 25 líderes europeos a principios de marzo de 2012, fue el ápice de una serie larga de medidas ${ }^{11}$. Este Tratado representa sólo uno de los eslabones de una cadena más larga de medidas adoptadas para luchar contra la crisis de la UE (nos referimos a la creación de la Facilidad Europea de Estabilización Financiera [FEEF], el Mecanismo Europeo de Estabilización Financiera [MEEF], el Pacto Euro Plus, la modificación del art. 136 del TFUE, el Mecanismo Europeo de Estabilidad [MEDE], los llamados sixpack y two-pack o paquetes de seis y dos medidas, entre otros) $)^{12}$.

Con todas estas iniciativas, la UE ha tratado de lograr un nuevo sistema integrado de vigilancia de las políticas presupuestarias y económicas y un nuevo calendario presupuestario. Se ha insistido mucho en el establecimiento de reglas claras y en una mejor coordinación de las políticas nacionales, así como en establecer sanciones de forma más rápida.

Todas estas medidas se ejecutan en paralelo. Algunas de ellas son parte del ordenamiento jurídico de la UE (por ejemplo, el six pack, el two pack), mientras que otras no lo son; algunas son interdependientes (como ciertos aspectos del six pack y del TECG), mientras que otras no (por ejemplo el Pacto Euro Plus referente a competitividad y el TECG, enfocado en la austeridad). Esto explica por qué ciertos Estados miembros participan solo en algunas acciones y no en otras.

Los mencionados desarrollos son el escenario común a toda la literatura mencionada en este artículo. Esta literatura también comparte la percepción de que la crisis (o las crisis) son una fuente potencial de transformación de la UE, constituyen una oportunidad de desarrollo.

\section{EL CONCEPTO DE MUTACIÓN CONSTITUCIONAL}

Antes de proceder con el análisis del impacto de la crisis, debemos aclarar qué entendemos por «mutación» en el contexto de este artículo. Como es

${ }^{11}$ L. Besselink y J. H. Reestman, The Fiscal Compact and the European Constitutions: 'Europe Speaking German', European Constitutional Law Review, 2012, p. 1-7; House of Commons European Scrutiny Committee, Treaty on Stability, Coordination and Governance: Impact on the Eurozone and the Rule of Law, 2012, <www.publications.parliament.uk/pa/cm201012/cmselect/cmeuleg/1817/1817.pdf>; I. PERNICE, International Agreement On A Reinforced Economic Union. Legal Opinion, 2012, <www. greens-efa.eu/international-agreement-on-a-reinforced-economic-union-5125.html $>$.

${ }^{12}$ G. Bianco, The New Financial Stability Mechanisms and Their (Poor) Consistency with EU Law, EUI RSCAS 2012/44, 2012, <cadmus.eui.eu/handle/1814/23428>; A. KoCHARov A. (ed.), Another Legal Monster? An EUI Debate on the Fiscal Compact, EUI Law Working Paper, 2012/09, 2012, <cadmus.eui.eu/bitstream/handle/1814/21496/ LAW_2012_09_Kocharov_ed.pdf?sequence $=1>$. 
bien conocido, este es un concepto desarrollado principalmente por la escuela alemana, en particular por JELLINEK ${ }^{13} \mathrm{y}$, recientemente, se ha utilizado para describir los efectos de la crisis en el marco institucional europeo ${ }^{14}$. Como recuerda PERNICE «it was very early that the German Constitutional Court recognised the mere fact, that although no explicit textual changes are made in the Constitution, the progress of European integration implies substantial 'material' modifications of the contents of the Constitution, a phenomenon which Hans Peter Ipsen has called 'constitutional mutation'. Those are the implications of art. 24 I GG, which allows the transfer of the sovereignty by simple legislative act, and of the general acceptance of the autonomy and supremacy of community law even over the Constitution ${ }^{15}$. Bruno DE WITTE ha puesto en cuestión sin embargo la aplicabilidad de este concepto a la crisis europea, optando por la idea de «variación institucional» ${ }^{16}$ :

${ }^{13}$ G. Jellinek, Mutamento e riforma costituzionale (traducción italiana), Lecce, Cavallino Pensa, 2004, donde se hace una distinción entre revisión y mutación constitucional «la prima caratterizzata dall'essere il frutto di 'azioni volontarie e intenzionali' e la seconda il frutto di fatti che non necessariamente sono accompagnati dall'intenzione o dalla coscienza di tale cambiamento» (M. LuCIANI, Dottrina del moto delle costituzioni e vicende della costituzione repubblicana, Osservatorio sulle fonti, 2013, p. 1-28, p. 5).

${ }^{14}$ C. Closa, Los cambios institucionales en la gobernanza macroeconómica y fiscal de la UE: hacia una mutación constitucional europea, Revista de estudios políticos, 2014, pp. 65-94.

${ }^{15}$ I. PERNICE, Constitutional Law Implications for a State Participating in a Process of Regional Integration. German Constitution and 'Multilevel Constitutionalism', en E. RIEDEL, (eds.) German Reports on Public Law. Presented to the XV International Congress on Comparative Law, Baden-Baden, NOMOS, 1998, p. 40-66, <http://www.whi-berlin.eu/ documents/pernice-regional-integration.pdf $>$. H. P. IPSEN, Europäisches Gemeinschaftsrecht, Mohr Siebeck Verlag, Tübingen, 1972, 58.

16 B. DE WITTE, «Euro Crisis Responses and the EU Legal Order: Increased Institutional Variation or Constitutional Mutation?», European Constitutional Law Review, Vol. 11/3, 2015, p. 434-457, p. 444-445: "The institutional metamorphosis which EMU law underwent after 2010, and which was roughly sketched in the first part of this article, has caused turbulence also in legal writing. Legal scholars have sought to interpret this evolution in various ways. In this second part of the article, two different accounts will be discussed, which are differentiated by the extent to which they consider the recent evolution to have affected the EU's overall constitutional order... The first account is a radical one. It argues that either single euro crisis reforms or their cumulative effect, have led to a mutation of the constitutional law of the European Union. Although the authors proposing such accounts often do not explain what they mean by 'constitutional mutation', a common characteristic of their assessment is a claim that interstitial changes in EMU law have spilled over into EU law generally, so as to modify and redefine the constitutional system laid down in the Lisbon Treaty...The second account is a more moderate one. It takes its cue from the fact that institutional rules have always varied across policy fields during the entire European integration process. This variation increased with the Maastricht Treaty, which (among other things) established Economic and Monetary Union as 
«The term 'constitutional mutation', or closely related terms, has been embraced by a large number of authors analysing the legal consequences of the euro crisis... Others have used the term constitutional mutation with regard to the substantive content of European economic governance rather than its institutional character, which raises a different set of questions that will not be considered here... Those broader arguments, finding that a constitutional mutation has taken place, can be grouped in four main categories: (i) the claim that the EU's institutional balance has been redefined; (ii) the claim that the principles of equality (of the EU member states) and of unity (of the EU legal order) have been set aside; (iii) the claim that political expediency has repeatedly prevailed over legal normativity, denoting a massive decline of the rule of law; and (iv) the claim that the relation between EU and national law has been transformed, through a major limitation of the budgetary sovereignty of the 'bail-out' countries in particular» ${ }^{17}$.

La erosión de la igualdad de los Estados miembros y el orden jurídico de la unidad ${ }^{18}$, el retorno al intergubernamentalismo ${ }^{19}$, la violación de la rule of $l a w^{20}$ y la reducción de la soberanía financiera de los países que se han beneficiado de programas de asistencia financiera debido a los mecanismos de condicionalidad $^{21}$ son los principales ejemplos de mutaciones constitucionales registrados por los autores mencionados, (y criticados) por DE WiTTE. Este ultimo, como se señaló, muestra una preferencia por el concepto de «variación institucional».

an institutionally very idiosyncratic policy area. This institutional distinctiveness was not affected, and even slightly reinforced, by later Treaty revisions, including the Lisbon Treaty. The euro crisis response is marked by a further increase in this institutional variation within EU law, between EMU law and other areas, but the overall constitutional system, as last re-arranged by the Lisbon Treaty, is not affected in a major way».

17 B. DE WiTTE, Euro Crisis Responses and the EU Legal Order cit., p. 447-448.

18 B. DE WITTE, Euro Crisis Responses and the EU Legal Order cit, p. 450.

19 «A shift in the EU's institutional balance away from the supranational institutions and the 'Community method' and towards the intergovernmental institutions and arenas», B. DE WITTE, Euro Crisis Responses and the EU Legal Order cit, p. 448.

${ }^{20}$ «The main political actors have deliberately ignored legal constraints in the name of political expediency», B. DE WITTE, Euro Crisis Responses and the EU Legal Order cit, p. 451 .

${ }^{21}$ «The final type of «mutation» claim is specifically related to the position of those countries (both within the euro area and outside) that have received financial assistance either from the EU itself or from one of the international financial «vehicles» (mainly the European Stability Mechanism, currently). The conditionality imposed under those financial assistance programmes (which is mandated, as far as the ESM is concerned, by the newly added Article 136(3) TFEU) includes very detailed instructions regarding the state budgets both on them revenue and on the spending side», B. DE WITTE, Euro Crisis Responses and the EU Legal Order cit., p. 452. 
Varias son las razones que llevan a DE WITTE a esta crítica: en primer lugar los cambios importantes producidos en la unión monetaria no son capaces, según este autor, de alterar el equilibrio global del proceso de integración $^{22}$. Además, el segundo pilar del Derecho supranacional -el principio de primacía- no se ha visto cuestionado por los cambios introducidos por el nuevo gobierno económico europeo:

«I do not see evidence of a brutal setting aside of the rule of law in the name of political expediency, but rather a major effort to deal with urgent matters in a constitution-compatible way. Nor do I see a threat to the primacy of EU law in the fact that a number of international side agreements were concluded, since the state parties, in all of those agreements, sought to preserve the precedence of EU law, and since the main action in EMU matters is still (or again) very much embedded within the EU institutional structure».

En otras palabras, para DE WITTE, la fórmula «mutación constitucional» sería excesiva, porque no responde al tipo de impacto producido por las medidas anticrisis, impacto que no cabe ignorar, pero tampoco suficiente para alterar profundamente la estructura constitucional europea. Por todas estas razones, el autor prefiere el concepto, menos exigente, de «variación institucional».

Sin embargo, las fórmulas en cuestión no deben necesariamente ser leídas de una forma antitética: el concepto de mutación es suficientemente grande como para absorber la idea de variación. Por Verfassungswandlung, BÖCKENFÖRDE se refería a un «cambio de contenido de las normas constitucionales que no implique un cambio en su texto $»^{23}$. Para probar la amplitud del concepto se puede mencionar que, para HsU DAU-LiN ${ }^{24}$, por ejemplo, por «mutación» se puede hacer referencia al menos a cuatro fenómenos

${ }^{22}$ «The constitutional mutation thesis, despite its popularity in the scholarly literature, and despite a number of plausible features (especially on the issue of budgetary sovereignty of the programme countries), is not convincing as an overall account of the crisis induced institutional changes - not only for the reason, discussed in the pages above, that it tends to overstate the legal-constitutional impact of the institutional changes within EMU law, but also because it tends to extrapolate too easily overall changes in the EU legal order from the specific changes that occurred within the special domain of EMU law. Indeed, Economic and Monetary Union is only part of the overall European integration project, although at times it seems to overshadow everything else», B. DE WITTE, Euro Crisis Responses and the EU Legal Order cit, p. 453.

${ }^{23}$ E.W. BöCKENFÖRDE, Note sul concetto di mutamento costituzionale, en Stato, costituzione, democrazia. Studi di teoria della costituzione e di diritto costituzionale, Milano, Giuffrè, 2006, 608.

${ }^{24}$ HsÜ DAU-LIn, Die Verfassungswandlung, Berlin, De Gruyter, 1932. 
diferentes, siendo sólo uno de ellos referente a las mutaciones contra constitutionem $^{25}$.

Dicho esto, en este artículo en particular, por «mutación» no se considerará una ruptura total con la estructura constitucional anterior, esto se hará evidente a partir del comienzo del análisis, en el que vamos a tratar de poner de relieve tanto la continuidad, como la discontinuidad con el pasado. De esta forma, la idea de la variación institucional puede quedar incluida en la más amplia idea de mutación.

\section{ASIMETRÍA E INTERGUBERNAMENTALISMO}

Si se mira a la nueva gobernanza económica desde la perspectiva de los expertos en Derecho constitucional, se pueden identificar dos factores importantes de la transformación constitucional: por un lado, un aumento de la asimetría de la integración; y por otro, un aumento de las dinámicas intergubernamentales. En efecto, la nueva gobernanza económica europea amplifica la dimensión asimétrica de la UE: en primer lugar, algunas de las medidas anteriormente mencionadas en este artículo han sido adoptadas fuera del marco legislativo de la UE, a través de la celebración de acuerdos internacionales (como el TECG y el MEDE). Esta elección dio lugar a la creación de un conjunto de reglas compartidas por solo algunos de los Estados miembros de la UE, en forma de Tratado de Derecho internacional público. En segundo lugar, el carácter asimétrico de la gobernanza económica podría ser ampliado si se recurre a una cooperación reforzada, cuyo uso posibilita el TECG (Art. 10).

Empezando por el primer factor, el aumento de la asimetría, gracias al TECG, como ha subrayado Rossi ${ }^{26}$, se ha creado un sistema en forma de diversos círculos concéntricos:

- Un primer círculo está representado por los Estados miembros de la UE de la zona euro que han ratificado el TECG (al menos «siempre que doce Partes Contratantes cuya moneda es el euro hayan depositado su instrumento de ratificación», de acuerdo con el art. 14 TECG).

- Un segundo grupo está formado por los Estados que no pertenecen a la zona euro, pero que han ratificado el TECG (por ejemplo Polonia).

- Un tercer círculo incluye a los Estados que no participan en el Pacto por el Euro Plus, pero que han ratificado el TECG (por ejemplo Hungría).

${ }^{25}$ Como recuerda R. IBRIDO, L'interpretazione del diritto parlamentare. Politica e «diritto nel processo» di risoluzione dei casi regolamentari, Roma, Franco Angeli, p. 125.

${ }^{26}$ L. S. Rossi, L.S., Fiscal Compact e conseguenze dell'integrazione differenziata nell'Ue, en G. Bonvicini-F. Brugnoli, F. (eds.), Il Fiscal Compact, Roma, Edizioni Nuova Cultura, 2012 p. 29-34. 
Se desprende de este escenario que el TECG va a ampliar la geometría variable de la UE, enfatizando esta característica asimetría de la gobernanza económica de la UE.

Sin embargo, la asimetría no es per se un «mal constitucional $»^{27}$. Por ejemplo, la flexibilidad y la asimetría son dos de las características más importantes del federalismo canadiense, elementos en parte explicables por la diversidad jurídica, cultural y económica del territorio.

La asimetría se ha experimentado frecuentemente dentro de los federalizing processe ${ }^{28}$, especialmente en aquellos contextos federales, o casi federales $^{29}$ que se caracterizan por la coexistencia de diferentes orígenes culturales y jurídicos (Canadá, por ejemplo).

Hay que tener esto en cuenta antes de valorar, por ejemplo el uso en aumento de la cooperación, como una forma de «mal constitucional», que pueda conducir automáticamente a la desintegración de la UE.

Al contrario, la asimetría podría incluso servir como un instrumento de integración constitucional, como demuestra el Derecho comparado ${ }^{30}$. Como hemos mencionado, la flexibilidad y la asimetría son dos de las características más importantes del federalismo canadiense y también de muchos otros federalismos multinacionales:

«Asymmetry can be defined as a feature of multinational federal systems through which nationality-based units (NBUs; home to national minorities) de jure enjoy more rights than regional-based units ... and maintain a differentiated relationship to the center (Kymlicka, 1998). This suggests that the stability of asymmetrical federal political systems depends on the interaction of a complex set of actors defined by both the majority - minority and the center - regional divide» ${ }^{31}$.

27 C. TARLton, Symmetry and Asymmetry as Elements of Federalism: A Theoretical Speculation, Journal of Politics, 1965, p. 861-874 «Symmetry refers to the extent to which component states share in the conditions and thereby the concerns more or less common to the federal system as a whole. By the same token, the second term, the concept of asymmetry expresses the extent to which component states do not share in these common features», p. 861.

${ }^{28}$ F. PAlermo, La coincidenza degli opposti: l'ordinamento tedesco e il federalismo asimmetrico, 2007, <www.federalismi.it/nv14/articolo-documento.cfm?artid=6991>.

${ }^{29}$ K.WheAre, Federal government, Oxford University Press, 1953, p. 20.

${ }^{30}$ F. PAlermo, Divided We Stand. L'asimmetria negli ordinamenti composti, en A. Torre, L. Volpe, G. Cerrina Feroni, E. Ceccherini, A. Rinella, M, Carducci, C. CAsonato y T. Frosini, (eds.), Processi di devolution e transizioni costituzionali negli Stati unitari (dal Regno Unito all'Europa), Torino, Giappichelli, 2007, p. 149-170; R. WATTS, A Comparative Perspective on Asymmetry in Federations, 2005, <www.iigr.ca>.

${ }^{31}$ C. I. ZuBER, Understanding the Multinational Game: Toward a Theory of Asymmetrical Federalism, Comparative Political Studies, 2011, p. 546. Véase también W. SweNDEN, Asymmetric Federalism and Coalition-Making in Belgium, Publius, 2002, p. 67. 
Por tanto, la asimetría puede dar valor añadido al proceso, siempre y cuando se respete el núcleo duro del ordenamiento, sus valores fundamentales. Sin embargo, normalmente para garantizar la función integradora de estos instrumentos, los ordenamientos reconocen un conjunto de garantías, ya sean sustanciales o procedimentales (véase los art. 20 TUE y art. 326 TFUE, por ejemplo) para evitar que esta diferenciación pueda conducir a una revolución en el sentido técnico de la palabra. Estas garantías sirven para hacer de la asimetría un cambio sostenible. Un número de garantías insuficientes, en nuestra opinión, es la razón que nos provoca dudas sobre la compatibilidad del art. 10 del TECG con los Tratados de la UE.

Por mucho tiempo la asimetría ha sido concebida como la excepción en los sistemas federales ${ }^{32}$ porque era vista como algo que afectaba a la igualdad de las partes del foedus. Sin embargo, los estudiosos han demostrado ampliamente que hoy todos los sistemas federales conocen formas de asimetría ${ }^{33}$.

Otra previsión relevante para analizar la cuestión asimétrica en la gobernanza económica dibujada por el TECG es su art. 10, dedicado a la cooperación reforzada. Sobre este artículo en particular hemos desarrollado un artículo que trata de demostrar sus ambigüedades ${ }^{34}$.

El art. 10 del TECG menciona sólo la imposibilidad de amenazar el mercado interior, sin referirse, sin embargo, al resto de elementos que especifica literalmente el art. 326 del TFUE (es, decir «la cohesión económica, social y territorial», la necesidad de no crear obstáculos o discriminaciones «para los

32 A. LA Pergola, Residui contrattualistici e struttura federale nell'ordinamento degli Stati Uniti, Milano, Giuffrè, 1969.

${ }_{33}$ F. PAlermo, La coincidenza degli opposti cit.

${ }^{34}$ C. M. Cantore-G. Martinico, Asymmetry or Dis-integration? A few considerations on the new 'Treaty on Stability, Coordination and Governance in the Economic and Monetary Union, European Public Law, 2013, p. 463-480. Si comparamos el texto del artículo 10 del TECG con el de los artículos 20 del TUE y 326 del TFUE, se pone en evidencia una cierta incoherencia textual, más visible aun en la versión inglesa, del artículo 10 del TECG: "In accordance with the requirements of the Treaties on which the European Union is founded, the Contracting Parties stand ready to make active use, whenever appropriate and necessary...of enhanced cooperation, as provided for in Article 20 of the Treaty on European Union and in Articles 326 to 334 of the Treaty on the Functioning of the European Union on matters that are essential for the proper functioning of the euro area, without undermining the internal market». ¿Expresiones como «whenever appropriate and necessary» o «active use» son compatibles con la idea según la cual la cooperación reforzada debe ser la opción de «último recurso»? Estas fórmulas literales parecen introducir un elemento ajeno a la idea de «extrema ratio» codificada en los Tratados fundamentales. Nos parece que estos elementos introducen un elemento de oportunidad que puede abrir la puerta a una discrecionalidad mayor para los Estados en el uso del mecanismo. 
intercambios entre Estados miembros», y de no provocar «distorsiones de competencia entre ellos»). El único sentido que este artículo puede tener, en nuestra opinión, es la posibilidad de que sea utilizado para realizar la incorporación ex art. 16 TCG, la comunitarización de los contenidos del Fiscal Compact, siendo una alternativa a la opción de revisar los Tratados.

Otro elemento que ha alimentado muchas críticas a la nueva gobernanza económica europea es la tendencia en su seno de volver a los mecanismos de Derecho público internacional. Esta tendencia ha sido interpretada como un retorno al intergubernamentalismo y como una pérdida en términos de supranacionalismo. Efectivamente este es un argumento frecuentemente utilizado para cuestionar la legitimidad del nuevo gobierno económico europeo. Sin embargo, como FABBRINI ha demostrado, el uso de acuerdos diferenciados entre los miembros de una unión es conocida incluso en las experiencias federales ${ }^{35} \mathrm{y}$, como De WiTTE ha señalado, esta «vuelta a los tratados internacionales» no es algo nuevo ${ }^{36}$; este camino se ha seguido en otros casos en el pasado del proceso de integración comunitario.

Aunque esta no es la primera vez en la que se han empleado los instrumentos de Derecho internacional para hacer frente a una cuestión supranacional, los estudiosos no ven una estrategia común detrás de esta tendencia, en lugar de ello, este camino habría sido elegido debido principalmente a la flexibilidad que ofrece ${ }^{37}$. En este contexto, el TECG es peculiar por muchas razones, siendo la más evidente el hecho de que interviene en una situación ya dominada por la asimetría, añadiendo otra dosis de diferenciación ${ }^{38}$. La elección de fuentes jurídicas internacionales que se utilizan para hacer frente a la crisis revela otro detalle importante de la transformación constitucional introducida por los últimos desarrollos jurídicos. Este argumento ha sido desarrollado por CHITI y TEIXEIRA de una manera bastante clara: según ellos, «la reacción a la crisis de la UE ha ido abandonando progresivamente el método de la Unión y esto ha reforzado las dinámicas intergubernamentales $»^{39}$.

${ }^{35}$ F. FABBRINI, The enhanced cooperation procedure: a study in multispeed integration, Centre for Studies on Federalism Research Paper, 2012, <www.csfederalismo.it/ attachments/2433_CSF-RP_Fabbrini_ENHANCED\%20COOPERATION_October2012.pdf $>$.

${ }^{36}$ B. DE WiTtE, Using International Law in the Euro Crisis Causes and Consequences, ARENA Working Paper, 4/2013, 2013, <www.sv.uio.no/arena/english/research/publications/arena-publications/workingpapers/working-papers2013/wp4-13.pdf>.

37 B. DE WITTE, Using International Law in the Euro Crisis cit.

${ }^{38}$ L. S. Rossi, Fiscal Compact e conseguenze dell'integrazione differenziata nell'Ue, en G. Bonvicini y F. Brugnoli, (eds.), Il Fiscal Compact, Roma, Edizioni Nuova Cultura, 2012 p. 29-34.

39 E. ChItr y P. G. TeIXeIRA, The Constitutional Implications of the European Responses to the Financial and Public Debt Crisis, Common Market Law Review, 2013, p. 683-708. 
El hecho de que se haya desarrollado parcialmente la disciplina anticrisis fuera del ámbito de los Tratados de la UE, ha dado como resultado una mezcla de actos jurídicos de la UE que conviven con tratados internacionales, lo que conlleva problemas en términos de compatibilidad de algunas de las soluciones adoptadas en esta fase con la legislación de la UE. Por todas estas razones, la deuda soberana y la crisis financiera habrían provocado un peligroso proceso de transformación con una «departure from the traditional paradigm of the EU economic constitution» hasta el agotamiento de las «main democratic legitimacy sources of the EU polity»"

De hecho, muchos autores han argumentado que las últimas novedades normativas introducidas afectarían a la legitimidad y al carácter democrático del proyecto europeo y representarían en particular una fractura en la historia de su constitución económica y, más en general, un cambio en su paradigma constitucional. Este es el argumento desarrollado por DAWSON y DE WiTTE, por ejemplo, que han tratado de demostrar que las medidas anticrisis habrían alterado el «constitutional balance upon which the Union's stability is premised $\rangle^{41}$, su compromiso con el pluralismo y demostrarían la incapacidad de la UE para «accommodate the plurality of interests that distributive conflicts engender» ${ }^{42}$.

En opinión de estos autores, la crisis podría causar el abandono de la «relative neutrality of the Union's policies» ${ }^{43}$, debido a la necesidad de hacer frente a la crisis a través de la adopción de una ruta de austeridad, una sola de las varias opciones políticas posibles para salir de la crisis. Por otra parte,

${ }^{40}$ E. ChITI y P. G. TeIXeIRA, The Constitutional Implications cit., respectivamente, p. 685 y 706 .

${ }_{41}$ "The response to the euro-crisis destabilises the Union's substantive balance by circumventing its limited mandate in redistributive policies, which was meant to ensure that citizens have ownership and authorship over the core values that shape their society (the second section). It equally recalibrates the institutional balance by decreasing the voice of marginalised interests and representative institutions. This loss of representative influence is likely to result in greater power for national executives, with responsibilities for the initiation of, and compliance with, policy proposals shifting during the crisis towards the European Council (in the third section). Finally...the Union's response to the euro-crisis also threatens the spatial balance of the Union, which protects the voice of smaller and poorer Member States and their citizens from majoritarian or even hegemonic tendencies. The increased influence of the bigger, more resourceful Member States, in combination with the changes to the Union's substantive and institutional structure, leads to the loss of political autonomy for smaller and poorer Member States», M. DAWson y F. DE WITTE, Constitutional Balance in the EU after the Euro-Crisis, in Modern Law Review, 2013, p. 817-844, p. 817.

${ }^{42}$ M. DAWSON y F. DE WITTE, Constitutional Balance in the EU after the Euro-Crisis, Modern Law Review, 2013, p. 817-844, p. 822.

${ }^{43}$ M. Dawson y F. DE Witte, Constitutional Balance in the EU cit, p. 685 y 706. 
esta situación se vería agravada por la ausencia de una arena política, donde los parlamentos y los ciudadanos puedan participar y discutir las opciones políticas transnacionales, sin mencionar el reducido papel de la Comisión y el Parlamento Europeo en el creciente «executivism» de las políticas de la UE a favor del Consejo Europeo ${ }^{44}$.

Sin embargo, las relaciones intergubernamentales desarrollan un papel fundamental también en contextos democráticos sólidos. Casos como España, Bélgica, Canadá, Reino Unido son ricos como ejemplos. En Canadá, a la luz de la odisea constitucional que ha bloqueado las dinámicas constitucionales locales, acuerdos intergubernamentales como el Social Union Framework Agreement, han jugado un papel paraconstitucional ${ }^{45}$. La doctrina canadiense ha identificado varias funciones constitucionales desarrolladas por las relaciones intergubernamentales:

«Regardless of their status, however, agreements play at least five different functions: a) Firstly, and predictably, they are used to co-ordinate or harmonise policies between orders of government (who does what? who pays for what?). b) Secondly, agreements serve to manage process and procedure (how do they do it? how do they resolve disputes?).c) Thirdly, intergovernmental agreements can play a 'para-constitutional' function when they are used to circumvent the formal distribution of powers, or to formalise a convention. d) Fourthly, agreements can be instruments of 'regulation by contract', when they are used as tools of centralisation under the guise of compromise and consensus, or when, regardless of the formal distribution of powers, a party 'makes an offer' to another one which the latter 'cannot refuse...'. e) Finally, and in a related way, agreements are instruments of soft-law. Regardless of their legal standing, they tend to be negotiated, drafted and implemented by civil servants as if they were binding. This can be particularly problematic given the lack of parliamentary scrutiny which often surrounds their adoption $\rangle^{46}$.

${ }^{44}$ U. PUETTER, Europe's Deliberative Intergovernmentalism: The new role of the Council and European Council in EU Economic Governance, Journal of European Public Policy, 2012, p. 170-178.

${ }^{45}$ H. Lazar, The Social Union Framework Agreement: Lost Opportunity or New Beginning?, <www.queensu.ca/iigr/sites/webpublish.queensu.ca.iigrwww/files/files/ WorkingPapers/miscellaneous/LazarSocialUnion.pdf>; R. GIBBINS, Shifting Sands: Exploring the Political Foundations of SUFA, 2001, <www.irpp.org>; S. D. PHILIPS: SUFA and Citizen Engagement: Fake or Genuine Masterpiece?, <www.irpp.org>; M. MENDELSOHN y J. MCLEAN, SUFA's Double Vision: Citizen Engagement and Intergovernmental Collaboration, 2000, <www.irpp.org >.

46 J. PoIRIER, The Functions of Intergovernmental Agreements: Post-Devolution Concordats in a Comparative Perspective, <http://www.ceelbas.ac.uk/spp/publications/unitpublications/75.pdf>, 2001, p. 3. 
La UE ha respetado siempre un equilibrio entre las dinámicas intergubernamentales y supranacionales pero las recientes novedades introducidas por las medidas anti-crisis han cuestionado la validez analítica de esta distinción. Como han subrayado muy bien TORTOLA y VAI:

«It is a widely held view that the Eurozone crisis and its consequences have strengthened intergovernmentalism in the EU at the expenses of its supranational aspects (see for example Fabbrini 2013; Bickerton, Hodson and Puetter 2014). The ESM and the fiscal compact, two key tools in the EU's response to the crisis created entirely outside the "community method», are cases in point. More generally, the crisis has placed the European Council in a prominent position within the EU's institutional architecture. Prima facie, this «resurgence of intergovernmentalism» argument is not without merits. Upon closer inspection, however, it needs to be qualified in at least three respects. First, and most simply, one should not underestimate the room for manoeuvre that even mostly intergovernmental arrangements may leave for the enforcer of such mechanisms, which is often supranational in character. It is the case, for instance, of the Stability and Growth Pact and fiscal compact rules, which afford the Commission a significant degree of discretion in deciding how to interpret macroeconomic and budgetary criteria. Second, alongside the establishment or reinforcement of intergovernmental mechanisms in the area of macroeconomic governance, recently we have witnessed an equally important strengthening of supranational institutions that is often overlooked by intergovernmentalists. For one thing, the Eurozone crisis itself, and its consequences on citizens' political dissatisfaction, were key stimuli to the introduction of the Spitzenkandidaten process for selecting the Commission president, which in turn promises to increase both the European Parliament (EP)'s role and the Commission's autonomy vis-à-vis the member states in the years to come» ${ }^{47}$.

En conclusión, la impresión que uno obtiene a partir de la situación actual es la de una Unión Europea que está luchando con sus propios límites constitucionales, ejerciendo una presión muy fuerte sobre las instituciones y los actores nacionales (el caso griego e italiano son emblemáticos, desde este punto de vista $)^{48}$. Esto no parece coherente con las teorías constitucionales de Derecho europeo (pluralismo constitucional, por ejemplo) que

${ }^{47}$ P. TORTOLA y L. VAI, What government for the European Union? Five themes for reflection and Action, CSF-IAI WP Series, 2015, <www.iai.it/sites/default/files/iai1517. pdf $>$.

48 P. LINDSETH, Greek 'Sovereignty' and European 'Democracy' - a bit of a walkback, due to some 'colossal' concerns, 2012, <eutopialaw.com/2012/02/15/greek-sovereignty-and-european-democracy-a-bit-of-a-walk-back-due-to-some-colossal-concerns/>. 
enfatizan la idea de la cooperación y de la sinergia entre los diferentes niveles de gobierno ${ }^{49}$.

Además, como el derecho comparado muestra ${ }^{50}$, las crisis siempre han jugado un papel fundamental en la restructuración de la relación entre centro y periferia en los contextos regionales, federales o cuasi federales: en este sentido la crisis se presenta como importante momento de reflexión sobre la naturaleza misma del proceso de integración.

Probablemente lo que hemos visto con referencia al TECG no puede extenderse automáticamente a otras medidas europeas anticrisis, en primer lugar el Tratado MEDE. En este contexto, de hecho, las limitaciones de soberanía y las cuestiones institucionales relacionadas con la igualdad de los Estados miembros parecen más evidentes. Por otra parte, hay también muchas analogías entre el TECG y el MEDE y más en general muchas de las cuestiones que ahora están caracterizando el proyecto europeo parecen estar conectadas a los problemas históricos de la integración económica: la debilidad de la arquitectura económica europea (véase la distinción entre política monetaria y económica), repetida como mantra en los asuntos Pringle ${ }^{51}$ y Gauweiler $^{52}$ por el TJUE. Aquí, una vez más, todas las insuficiencias y clichés de la integración supranacional aparecen de nuevo, revelando sus antiguas raíces.

\section{TITLE: The Constitutional Implications of the Crisis. A Review Article}

RESUMEN: El objetivo de este artículo es ofrecer una panorámica de la literatura más relevante sobre las implicaciones constitucionales derivadas de la crisis de la Unión europea (UE). Mi análisis explora las principales opiniones doctrinales sobre las mutaciones de la estructura constitucional de la Unión producidas por la crisis. Con este propósito el término «mutación constitucional» no debe entenderse como una comple-

${ }^{49}$ D. Halberstam, Constitutional Heterarchy: The Centrality of Conflict in the European Union and the United States, en J. Dunoff y J. Trachtman, (eds.), Ruling the World? Constitutionalism, International Law and Global Governance, Cambridge, Cambridge University Press, 2009, p. 326-355.

${ }_{50}$ Se vean los ejemplos reportados por: J.J. WALlis y W. OATES, The Impact of the New Deal on American Federalism, en M. Bordo y C. Goldin (eds.), The Defining Moment: The Great Depression and the American Economy in the Twentieth Century, Chicago, University of Chicago Press, 1998, p. 155-180; A. LouberT, Sovereign Debt Threatens the Union: The Genesis of a Federation, European Constitutional Law Review, 2012, p. 442-455.

51 TJUE, C-370/12, Thomas Pringle / Government of Ireland, Ireland, The Attorney General, $<$ www.curia.europa.eu $>$.

52 TJUE, C-62/14, Gauweiler, <www.curia.europa.eu>. 
ta ruptura con el pasado y de hecho a lo largo de este artículo trataré de enfatizar las continuidades y interrupciones en la visión tradicional del proceso de constitucionalización de la UE.

PALABRAS CLAVE: Mutación constitutional, crisis, TECG.

ABSTRACT: The aim of this article is to offer an overview of the relevant literature devoted to the constitutional implications of the European Union (EU) crisis. My analysis explores the main scholarly views on the mutations of the constitutional structure of the Union produced by the crisis. To this purpose I do not conceive "constitutional mutation» as a complete rupture from the past and in fact in this piece I shall try to stress both continuities and discontinuities with the traditional understanding of the EU constitutionalization process.

KEY WORDS: Constitutional mutation, crisis, TSCG.

RECIBIDO: 18.04 .2016

ACEPTADO: 22.06.2016 